\title{
Examining the Factors Affecting University Students' Participation in Recreational Activities
}

\section{Examen de los factores que afectan la participación de los estudiantes universitarios en actividades recreativas}

\section{Serkan Çelik}

Faculty of Tourism, Recreation Management Department, University of Kâtip Çelebi / Izmir, Turkey ORCID ID: https://orcid.org/ 0000-0002-6236-8025

\section{İbrahim Dalbudak}

Atabey Vocational School, Isparta University of Applied Sciences / Isparta, Turkey ORCID ID: https://orcid.org/ 0000-0003-2380-803X 


\section{Summary}

This research is a study with the aim of determining the factors that affect the participation of students from different faculties in the university in recreational activities. Thus, it is aimed to reveal the factors affecting the participation of students from different faculties in the university to recreational activities and to develop recommendations on what they should do about their participation in recreational activities given to universities in the current laws. There are many factors that affect the leisure time preferences of individuals. Determining these elements will guide planners and managers in determining the adequacy, content and appropriateness of recreation and leisure activities to be developed. In the study, students from different faculties in the university participated in the survey with the participation of a total of 156 volunteers, 98 female and 58 male, in the province of İzmir. As a data collection tool, the "Personal Information Form" and the data related to the factors (motivation) that affect participation in recreational activities were obtained by using the scale developed by Beard and Ragheb (1980 and 1983) and adapted to Turkish by Karl1 et al. (2008). The scale consists of 34 items. The data obtained were analyzed using the SPSS 23 program. It was tested with "t-test", "ANOVA" to obtain statistical results. "Tukey post hoc" test was used to determine which groups caused the significant difference. As a result of the research, when the factors affecting students' participation in recreational activities were examined, it was concluded that the factor with the highest average is "to discover new things". The statement with the lowest average in the scale was "to gain the respect of others". In addition, according to the sub-dimension averages, it was seen that the most effective factor in the participation of individuals in recreational activities was the unattractive attractive factors, and the least important factor was sociability.

Keywords: Free Time, Leisure time, University Student, Participation in Recreation Activities.

\section{Resumen}

Esta investigación es un estudio con el objetivo de determinar los factores que inciden en la participación de estudiantes de diferentes facultades de la universidad en actividades recreativas. Así, se busca revelar los factores que inciden en la participación de estudiantes de diferentes facultades de la universidad a las actividades recreativas y desarrollar recomendaciones sobre lo que deben hacer sobre su participación en las actividades recreativas que se dan a las universidades en las leyes vigentes. Hay muchos factores que afectan las preferencias de los individuos en cuanto al tiempo libre. La determinación de estos elementos guiará a los planificadores y administradores a determinar la idoneidad, el contenido y la idoneidad de las actividades de recreación y esparcimiento que se desarrollarán. En el estudio, estudiantes de diferentes facultades de la universidad participaron en la encuesta con la participación de un total de 156 voluntarios, 98 mujeres y 58 hombres, en la provincia de İzmir. Como herramienta de recopilación de datos, el "Formulario de información personal" y los datos relacionados con los factores (motivación) que afectan la participación en actividades recreativas se obtuvieron utilizando la escala desarrollada por Beard y Ragheb (1980 y 1983) y adaptada al turco por Karl. et al. (2008). La escala consta de 34 ítems. Los datos obtenidos se analizaron mediante el programa SPSS 23. Se probó con "t-test", "ANOVA" para obtener resultados estadísticos. Se utilizó la prueba "Tukey post hoc" para determinar qué grupos causaron la diferencia significativa. Como resultado de la investigación, cuando se examinaron los factores que inciden en la participación de los estudiantes en actividades recreativas, se concluyó que el factor con mayor promedio es "descubrir cosas nuevas". La afirmación con el promedio más bajo en la escala fue "ganarse el respeto de los demás". Además, de acuerdo con los promedios de la subdimensión, se observó que el factor más efectivo en la participación de los individuos en actividades recreativas fueron los factores poco atractivos - atractivos, y el factor menos importante fue la sociabilidad.

Palabras clave: Tiempo libre, tiempo libre, estudiante universitario, participación en actividades recreativas. 


\section{Introduction}

In the century we live in, we can see that as a result of the rapid increase in technological and scientific developments, great convenience in living conditions, and the decrease in working hours, people's leisure time has increased with the increase in education and income levels as well (Tolukan, 2010).

When it comes to leisure time, our overall belief is explained as "non-working time" or "time remaining from work" because leisure time refers to the time that a person devotes to him/herself. In other words, leisure time includes the time remaining after fulfilling the personal, family, professional and social responsibilities that the person has to do and all the activities carried out at this time.

It is defined as the time period that the individual can use freely (Broadhurst, 2001), the time when the individual is free from all obligations or connections for him/herself and others and will deal with an activity that s/he will choose at his/her own will (Tezcan, 1993), the time that the individual will devote to individual preferences other than the struggles that he has to apply to live. is a special area of human life with its benefits, which include satisfaction and increase personal satisfaction, the chance of choice, creativity, and entertainment-leading benefits (Özdemir \& Karaküçük, 2006), rest, relaxation, increasing knowledge and manners, achieving satisfaction in psychological and physiological pleasures (Yetim, 2005). When leisure time is spent positively, it will motivate the person and keep the individual away from stress and depression, which will provide personal and social development. It would not be correct to consider the time spent in the course at the university as leisure time. While there are rules that a student must follow while attending a class, leisure time includes the time that a person becomes him and devotes to him in free times.

Among the fields of education, especially the university period is a time period that prepares the ground for personal and social development and prepares us for business life. If we look at the purpose of individual's coming to life, we see in philosophical and sociological explanations that the main goal and source of happiness is "self-realization". As long as a person can realize him and produce something, he will be a healthy person. Because this level that people should reach also states that the individual can recognize him, discover his working potential (Akınoğlu, 2005). Recreational activities provide positive assistance to individuals in many different ways such as creating physical health development, improving mental health, improving individual skills and abilities, and making the individual happy. It is seen that universities play a more functional role in the organization of recreational activities, which have an important place in the social lives of individuals and societies (Mete \& Ağaoğlu, 2003). Recreational activities emerge as an important concept in terms of mental performance increase, creativity and cultural developments in people. In particular, students who receive academic education in universities can be successful in scientific and social life, and their cultural, social and skill equipment is also a factor in their academic background (Yağmur, 2006). In overall, recreational activities can be defined as activities that people participate voluntarily in their leisure time, with the motives of entertainment and satisfaction. Recreational activities provide physical, spiritual and creative power to people by relieving their physical and mental fatigue (Sağcan, 1986).

Individuals gain important behavioral styles throughout their education and training lives. The most prominent of these processes is the university period. The positive habits that individuals acquire are a process that will affect their entire lives and ensure that their lives are happy. Therefore, it is important to spend leisure time with artistic cultural activities. In addition, studies have shown that participation in leisure time activities positively affects the academic success of students.

The participation of university students in recreational activities has been the subject of many studies. University periods are not a period in which individuals can fully improve themselves only by dealing with the course. For many individuals, university periods are important in ensuring academic and socio-cultural development. At the same time, recreational activities positively affect many areas of human life (job satisfaction, life satisfaction, family life, etc.) (Aslan, 2009; Huang \& Carleton, 2003). The "habits of participating in recreational activities" that individuals will acquire during their university education will be able to continue in the future 
periods of their lives. To measure whether individuals can benefit from the leisure time activities they participate in, whether they meet their expectations and whether they are happy to participate in these activities, to take measures that will make them feel happier and more satisfied while taking advantage of their leisure time, and to improve the leisure time activities provided in line with their satisfaction levels, and even to expand the range of activities. Can provide important information (Karl1 et al., 2008).

According to the results of the model development studies carried out in the literature to determine the factors that prevent individuals from participating in recreational activities, It was revealed that the factors that prevent or restrict participation in the activities could be handled in three basic groups as individual, interindividual and structural. Considering the positive effects of participation in recreational activities, determining the factors that prevent participation in such activities is important both individually and socially (Temir \& Gürbüz, 2012). In some studies on university youth, it was revealed that the vast majority of youth do not know how to spend their leisure time or spend their leisure time with passive activities, but they were willing to participate in many active activities if they have opportunities (Demir, 2003).

\section{Methodology}

\section{Research Model}

In this study, descriptive and correlational survey methods, which are overall survey models, were used.

\section{Forming Volunteer Groups}

Students studying in different departments of the faculties at universities in İzmir, Turkey, participated in the study voluntarily.

\section{Data Collection Techniques}

As data collection techniques, Personal Information Form and Participation in Recreative Activities scale has been used.

\section{Personal Information Form}

In obtaining the data, the questions prepared by the researcher regarding demographic characteristics, including gender, age, educational background of the mother and father, economic status, income status of the family, game, leisure time activities and which faculty the recreation department should be, were used.

\section{Participation in Recreational Activities Scale}

The data on the "Personal Information Form" and the factors (motivation) that affect participation in recreational activities were obtained by using the scale developed by Beard and Ragheb (1980 and 1983) and adapted to Turkish by Karl1 et al. (2008). In the literature reviews, it is understood that the questionnaire was accepted and used by local and foreign researchers (Loundsbury and Polik., 1992; Kanters and Forrester 1997; Ryan and Glendon, 1998; Starzyk et al., 2000; Beggs et al., 2004; Karlı et al. 2008; Beggs and Elkins 2010; Yağmur, 2015; Yağmur and İçigen, 2016; Yurcu, 2017; Kement et al., 2019; Soybalı et al., 2020). The scale consists of 32 items and it is understood that it has four dimensions (intellectual, social, competence mastery, unattractiveattractive).

\section{Distribution of Demographic Features}

Table 1. Demographic Distribution of the Individuals Participating in the Study

\begin{tabular}{|c|c|c|c|c|c|}
\hline & Frequeny & $\begin{array}{c}\text { Percentae } \\
(\%)\end{array}$ & & $\begin{array}{c}\text { Frequeny } \\
\text { Percentage } \\
(\%)\end{array}$ \\
\hline \multicolumn{3}{|c|}{ Gender } & \multicolumn{2}{|c|}{ Family total monthly income level } \\
\hline Female & 98 & 62,8 & $1001-2000 \mathrm{TL}$ & 8 & 5,1 \\
\hline
\end{tabular}




\begin{tabular}{|c|c|c|c|c|c|}
\hline Male & 58 & 37,2 & $2001-3000 \mathrm{TL}$ & 36 & 23,1 \\
\hline Total & 156 & 100.0 & $3001 \mathrm{TL}$ and above & 112 & 71,8 \\
\hline \multicolumn{3}{|c|}{ Income level } & Total & 156 & 100,0 \\
\hline $\begin{array}{l}1000 \mathrm{TL} \text { and } \\
\text { below }\end{array}$ & 110 & 70,5 & \multicolumn{3}{|c|}{$\begin{array}{l}\text { Which faculty would you like the recreation department } \\
\text { to be in? }\end{array}$} \\
\hline $1001-1500 \mathrm{TL}$ & 22 & 14,1 & Faculty of Sport Sciences & 29 & 18,6 \\
\hline $\begin{array}{l}1501 \mathrm{TL} \text { and } \\
\text { above }\end{array}$ & 24 & 15,4 & Faculty of Tourism & 127 & 81,4 \\
\hline Total & 156 & 100,0 & Total & 156 & 100,0 \\
\hline \multicolumn{3}{|c|}{ Age group } & \multirow{2}{*}{\multicolumn{3}{|c|}{ How effective are games in recreational activities? }} \\
\hline $18-20$ & 32 & 205 & $\begin{array}{c}\text { How effective are gam } \\
\text { Verv efficient }\end{array}$ & & \\
\hline $21-23$ & 96 & 61,6 & Slightly effective & 27 & 17,3 \\
\hline $24-26$ & 18 & 11,5 & & & \\
\hline & & & Total & 156 & 100.0 \\
\hline 27 and above & 10 & 6,4 & \multicolumn{3}{|c|}{$\begin{array}{l}\text { What kind of recreational activities do you do in your } \\
\text { leisure time? }\end{array}$} \\
\hline Total & 156 & 100,0 & Sports & 50 & 32,1 \\
\hline \multicolumn{3}{|c|}{ Mother's Education Level } & Other activities & 106 & 67,9 \\
\hline Illiterate & 4 & 2,6 & Total & 156 & 100,0 \\
\hline Primary Education & 64 & 41,0 & & & \\
\hline High School & 48 & 30,8 & & & \\
\hline Bachelor & 38 & 24,3 & & & \\
\hline Master Degree & 2 & 1,3 & & & \\
\hline Total & 156 & 100,0 & & & \\
\hline \multicolumn{3}{|c|}{ Father's Education Level } & & & \\
\hline Primary Education & 56 & 35,9 & & & \\
\hline High School & 42 & 26,9 & & & \\
\hline Bachelor & 54 & 34,6 & & & \\
\hline Master Degree & 4 & 2,6 & & & \\
\hline Total & 156 & 100,0 & & & \\
\hline
\end{tabular}

Relations between Demographic Findings

The Scale of Participation in Recreational Activities 
It consists of 32 questions in total. Scoring $\rightarrow$ strongly agree: 5, agree: 4, neither agree nor disagree: 3 , disagree: 2 , strongly disagree: 1

1112

\section{Sub-Dimensions}

Intellectual $\rightarrow$ Item $1,2,3,4,5,6,7$ and 8

Social $\rightarrow$ Item $9,10,11,12,13,14,15$ and 16

Qualification - Mastery $\rightarrow$ Item 17, 18, 19, 20, 21, 22, 23 and 24

Unattractive - Attractive $\rightarrow$ Item 25, 26, 27, 28, 29, 30, 31 and 32

Table 2. Questions of the Factors Effective on Participation in Recreational Activities

\begin{tabular}{|c|c|c|c|c|c|c|c|c|c|}
\hline \multirow{2}{*}{ Dimensions } & \multirow{2}{*}{ Statements } & \multirow{2}{*}{ 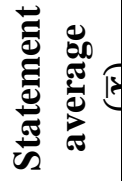 } & \multirow{2}{*}{ 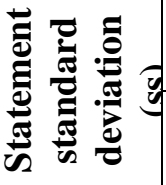 } & \multicolumn{6}{|c|}{ Descriptive summary statistics } \\
\hline & & & & $\bar{x}$ & SD & Min & Max. & Skewness & Kurtosis \\
\hline \multirow{8}{*}{ Intellectual } & $\begin{array}{l}\text { To be aware of the events around } \\
\text { me }\end{array}$ & 3,2692 & 1,0856 & \multirow{8}{*}{4,0473} & \multirow{8}{*}{0,5863} & \multirow{8}{*}{1,75} & \multirow{8}{*}{5,00} & \multirow{8}{*}{$-1,374$} & \multirow{8}{*}{1,656} \\
\hline & To satisfy my curiosity & 3,4551 & 0,9527 & & & & & & \\
\hline & To get new ideas & 4,3333 & 0,7648 & & & & & & \\
\hline & To know more about myself & 3,9103 & 0,8376 & & & & & & \\
\hline & To increase my knowledge & 4,3590 & 0,8795 & & & & & & \\
\hline & To discover new things & 4,4872 & 0,8150 & & & & & & \\
\hline & To be creative & 4,3910 & 0,8693 & & & & & & \\
\hline & To use my imagination & 4,1731 & 0,9716 & & & & & & \\
\hline \multirow{8}{*}{ Social } & To make friends with others & 3,6090 & 1,1105 & \multirow{8}{*}{3,4591} & \multirow{8}{*}{0,6593} & \multirow{8}{*}{1,38} & \multirow{8}{*}{4,88} & \multirow{8}{*}{$-0,617$} & \multirow{8}{*}{0,723} \\
\hline & To interact with others & 3,7821 & 1,0734 & & & & & & \\
\hline & To make close friendships & 3,1667 & 1,0085 & & & & & & \\
\hline & To meet new different people & 3,7436 & 1,1743 & & & & & & \\
\hline & $\begin{array}{l}\text { To reveal my thoughts, feelings } \\
\text { and physical abilities }\end{array}$ & 4,2051 & 0,6497 & & & & & & \\
\hline & $\begin{array}{l}\text { To be socially skillfull and } \\
\text { capable }\end{array}$ & 4,2179 & 0,7644 & & & & & & \\
\hline & To get a sense of belonging & 2,6090 & 1,1836 & & & & & & \\
\hline & To gain the respect of others & 2,3397 & 1,1556 & & & & & & \\
\hline \multirow{7}{*}{$\begin{array}{l}\text { Qualification } \\
\text { Mastery }\end{array}$} & To prove my talents & 2,5064 & 1,2926 & \multirow{7}{*}{3,8021} & \multirow{7}{*}{0,5997} & \multirow{7}{*}{2,50} & \multirow{7}{*}{4,88} & \multirow{7}{*}{$-0,313$} & \multirow{7}{*}{$-0,360$} \\
\hline & To be good at showing my talents & 2,7692 & 1,3043 & & & & & & \\
\hline & To improve my talents and skills & 4,2692 & 0,6153 & & & & & & \\
\hline & To be active & 4,2308 & 0,6988 & & & & & & \\
\hline & $\begin{array}{l}\text { To improve physical skills and } \\
\text { abilities }\end{array}$ & 4,2564 & 0,8414 & & & & & & \\
\hline & To keep my physical form & 4,1154 & 0,9702 & & & & & & \\
\hline & To use my physical abilities & 4,2372 & 0,8200 & & & & & & \\
\hline
\end{tabular}




\begin{tabular}{|c|c|c|c|c|c|c|c|c|c|}
\hline & To improve my physical form & 4,0321 & 1,1211 & & & & & & \\
\hline \multirow{8}{*}{$\begin{array}{l}\text { Unattractive- } \\
\text { Attractive }\end{array}$} & To get relaxed & 3,7115 & 0,9639 & \multirow{8}{*}{4,1002} & \multirow{8}{*}{0,6493} & \multirow{8}{*}{2,13} & \multirow{8}{*}{5,00} & \multirow{8}{*}{$-1,010$} & \multirow{8}{*}{0,359} \\
\hline & Sometimes as I like to be alone & 3,8910 & 1,1504 & & & & & & \\
\hline & To relax physically & 4,2115 & 1,0096 & & & & & & \\
\hline & To relax mentally & 4,4295 & 0,8733 & & & & & & \\
\hline & $\begin{array}{l}\text { To avoid the daily hustle and } \\
\text { bustle }\end{array}$ & 3,8526 & 1,1957 & & & & & & \\
\hline & To rest & 3,8269 & 0,9446 & & & & & & \\
\hline & To avoid stress and tension & 4,4487 & 0,7975 & & & & & & \\
\hline & To get my time out of routine & 4,4295 & 0,8432 & & & & & & \\
\hline \multicolumn{4}{|c|}{ Overall Scale } & 3,8522 & 0,4768 & 2,22 & 4,66 & $-0,814$ & 1,260 \\
\hline
\end{tabular}

When the factors affecting students' participation in recreational activities were examined in the table above, the statement with the highest average $(\bar{x}=4.4872)$ was "to discover new things". According to this statement, $5.1 \%$ of the students replied "disagree", 5.2\% of them replied "neither agree nor disagree", $25.6 \%$ of them replied "agree" and $64.1 \%$ of them replied "strongly agree". The statement with the lowest mean on the scale $(\bar{x}=2.3397)$ was "to earn the respect of others". $33.3 \%$ of the students replied "strongly disagree", $17.3 \%$ of them replied "disagree", $35.3 \%$ of them replied "neither agree nor disagree", $10.3 \%$ of them replied "agree" and $3.8 \%$ of them replied "I strongly agree". The average of the "intellectual" sub-dimension was 4.0473, the average of the "social" sub-dimension was 3.4591, the average of the "competence - mastery" sub-dimension was 3.8021, and the average of the "unattractive - attractive" sub-dimension was 4.1002. The overall average of the scale was found to be 3.8522. Since the skewness and kurtosis values of the sub-dimensions and the overall scale are between -2 and +2 , they provide the normal distribution assumption. In addition, according to the sub-dimension averages, it is seen that the most influential factor in individuals' participation in recreational activities is the unattractive attractive factors, the second most influential factor is intellectuality, the third most important factor is competence - mastery, and the least important factor is sociality.

\section{Interpreting the Relationship between Overall Scale and Its Sub-Dimensions with Pearson Correlation Coefficient}

Table 3. Pearson Correlation Coefficient Values

\begin{tabular}{|c|c|c|c|c|c|}
\hline & Overall Scale & Intellectual & Social & $\begin{array}{c}\text { Qualification } \\
\text { - Mastery }\end{array}$ & $\begin{array}{c}\text { Unattractive } \\
- \text { Attractive }\end{array}$ \\
\hline Overall Scale & 1,000 & $\begin{array}{c}0,791^{* *} \\
(0,000)\end{array}$ & $\begin{array}{c}0,865^{* *} \\
(0,000)\end{array}$ & $\begin{array}{c}0,646^{* *} \\
(0,000)\end{array}$ & $\begin{array}{c}0,748^{* *} \\
(0,000)\end{array}$ \\
\hline Intellectual & $0,791^{* *}$ & 1,000 & $\begin{array}{c}0,601^{* *} \\
(0,000)\end{array}$ & $\begin{array}{c}0,280^{* *} \\
(0,000)\end{array}$ & $\begin{array}{c}0,551^{* *} \\
(0,000)\end{array}$ \\
\hline Social & $0,865^{* *}$ & $0,601^{* *}$ & 1,000 & $0,513^{* *}$ & $0,509^{* *}$ \\
& $(0,000)$ & $(0,000)$ & & $(0,000)$ & $(0,000)$ \\
\hline Qualification - & $0,646^{* *}$ & $0,280^{* *}$ & $0,513^{* *}$ & 1,000 & $0,199^{*}$ \\
Mastery & $(0,000)$ & $(0,000)$ & $(0,000)$ & & $(0,013)$ \\
\hline Unattractive - & $0,748^{* *}$ & $0,551^{* *}$ & $0,509^{* *}$ & $0,199^{*}$ & 1,000 \\
Attractive & $(0,000)$ & $(0,000)$ & $(0,000)$ & $(0,013)$ & \\
\hline
\end{tabular}


* The correlation is significant at the 0,01 level.

** The correlation is significant at 0,05 level.

- Looking at the table, there is a statistically significant and same-directional relationship between the "overall scale" and all its sub-dimensions at 99\% confidence level. As the average score of any sub-dimension increases, the overall scale average score increases, or while the average score of any sub-dimension decreases, the overall scale average score also decreases.

- In addition, there is a statistically significant same-directional relationship between all sub-dimensions. Factors affecting individuals' participation in recreational activities affect each other positively.

\section{Scale reliability}

Table 4. Cronbach's Alpha Values of the overall scale and its sub-dimensions

\begin{tabular}{|c|c|}
\hline The Overall Scale and Sub-Dimensions & $\begin{array}{c}\text { Cronbach's Alpha } \\
\text { Value }\end{array}$ \\
\hline Overall Scale & 0,897 \\
\hline Intellectual & 0,805 \\
\hline Social & 0,793 \\
\hline Qualification - Mastery & 0,755 \\
\hline Unattractive - Attractive & 0,817 \\
\hline
\end{tabular}

Cronbach's Alpha value measuring the reliability of the "overall scale" that 156 individuals participated in was $\alpha=0.897$, the Cronbach's Alpha value measuring the reliability of the "intellectual" sub-dimension was $\alpha=0.805$, the Cronbach's Alpha value measuring the reliability of the "social" sub-dimension was $\alpha=0.793$, the Cronbach's Alpha value measuring the reliability of the "competence-mastery" sub-dimension was found to be $\alpha=0.755$, and the Cronbach's Alpha value measuring the reliability of the "unattractive - attractive" sub-dimension was found to be $\alpha=0.817$. The scale and its sub-dimensions are very consistent and reliable.

\section{Mean Score Distribution of Overall Scale and Sub-Dimensions by Demographic Variables}

In the tables below, the distribution of the overall scale and its sub-dimensions according to demographic variables and summary statistics are shown. Since the scale and sub-dimension mean scores provide the normal distribution assumption, the difference between the means of two independent groups was tested with the "t-test", and the difference between three or more group averages was tested by "one-way analysis of variance (ANOVA)". "Tukey post hoc" test was used to determine which groups caused the significant difference. The study was conducted at $\% 95$ significance level.

Table 5. The Results of the Students' Participation in Recreational Activities by Gender

\begin{tabular}{|c|c|c|c|c|c|c|}
\hline Gender & Intellectual & Social & $\begin{array}{c}\text { Qualificatio } \\
\text { n - Mastery }\end{array}$ & $\begin{array}{c}\text { Unattracti } \\
\text { ve - } \\
\text { Attractive }\end{array}$ & $\begin{array}{c}\text { Overall } \\
\text { Scale }\end{array}$ \\
\hline
\end{tabular}




\begin{tabular}{|c|c|c|c|c|c|c|}
\hline \multirow{2}{*}{ Female } & Mean & 4,0293 & 3,4783 & 3,7946 & 4,1824 & 3,8712 \\
\cline { 2 - 7 } St. Dev. & 0,6515 & 0,6951 & 0,6218 & 0,6108 & 0,4827 \\
\hline \multirow{2}{*}{ Male } & Mean & 4,0776 & 3,4267 & 3,8147 & 3,9612 & 3,8200 \\
\cline { 2 - 7 } & St. Dev. & 0,4593 & 0,5983 & 0,5654 & 0,6930 & 0,4690 \\
\hline \multicolumn{2}{|c|}{ p- value } & 0,621 & 0,638 & 0,841 & $0,039 *$ & 0,519 \\
\hline
\end{tabular}

Only the "unattractive - attractive" sub-dimension mean score values of individuals show statistically significant difference according to their gender. Accordingly, the unattractive attractive factors are more important in the selection of recreational activities for women. Average score values of women are higher than men.

Table 6. The Results of the Students' Participation in Recreational Activities by Income Level

\begin{tabular}{|c|c|c|c|c|c|c|}
\hline Income level & & Intellectual & Social & $\begin{array}{c}\text { Qualification } \\
\text { - Mastery }\end{array}$ & $\begin{array}{c}\text { Unattractive - } \\
\text { Attractive }\end{array}$ & $\begin{array}{c}\text { Overall } \\
\text { Scale }\end{array}$ \\
\hline $\begin{array}{c}\text { 1000 TL and } \\
\text { below }\end{array}$ & Mean & 4,1352 & 3,4466 & 3,7693 & 4,0943 & 3,8614 \\
\cline { 2 - 7 } & St. Dev. & 0,5169 & 0,7088 & 0,5481 & 0,6745 & 0,4763 \\
\hline \begin{tabular}{c} 
1001 - 1500 TL \\
\cline { 2 - 7 }
\end{tabular} & Mean & 3,8182 & 3,4886 & 3,5114 & 4,0568 & 3,7188 \\
\cline { 2 - 7 } & St. Dev. & 0,7741 & 0,4206 & 0,6442 & 0,6843 & 0,4459 \\
\hline $\begin{array}{c}\text { 1501 TL and } \\
\text { above }\end{array}$ & Mean & 3,8542 & 3,4896 & 4,2188 & 4,1667 & 3,9323 \\
\cline { 2 - 7 } & St. Dev. & 0,6142 & 0,6200 & 0,5946 & 0,5009 & 0,5011 \\
\hline \multicolumn{2}{|c|}{ p- value } & $0,014 *$ & 0,935 & $0,000^{*}$ & 0,838 & 0,297 \\
\hline
\end{tabular}

According to the income levels of individuals, "social", "unattractive - attractive" sub-dimension average score values and "overall scale" average scores do not differ significantly. In addition, "intellectualism" is more important in the selection of recreational activities of individuals with an income of $1000 \mathrm{TL}$ and less than individuals with higher income. "Competence - mastery" sub-dimension average score values are higher in individuals with an income of $1501 \mathrm{TL}$ and above than the individuals with less income.

Table 7. The Results of the Students' Participation in Recreational Activities by Age group

\begin{tabular}{|c|c|c|c|c|c|c|}
\hline Age group & Intellectual & Social & $\begin{array}{c}\text { Qualification - } \\
\text { Mastery }\end{array}$ & $\begin{array}{c}\text { Unattractive - } \\
\text { Attractive }\end{array}$ & $\begin{array}{c}\text { Overall } \\
\text { Scale }\end{array}$ \\
\hline
\end{tabular}




\begin{tabular}{|c|c|c|c|c|c|c|}
\hline \multirow{2}{*}{$\mathbf{1 8}-\mathbf{2 0}$} & Mean & 3,8516 & 3,3109 & 3,7719 & 3,7109 & 3,6113 \\
\cline { 2 - 7 } & St. Dev. & 0,5335 & 0,6019 & 0,4487 & 0,6564 & 0,4333 \\
\hline \multirow{2}{21-23}{} & Mean & 4,0003 & 3,4794 & 3,8242 & 4,1419 & 3,8115 \\
\cline { 2 - 7 } & St. Dev. & 0,6372 & 0,6725 & 0,5473 & 0,6297 & 0,5053 \\
\hline \multirow{2}{*}{$\mathbf{2 4 - 2 6}$} & Mean & 3,6750 & 3,5556 & 3,7639 & 4,4028 & 3,7688 \\
\cline { 2 - 7 } & St. Dev. & 0,2582 & 0,4205 & 1,0527 & 0,5777 & 0,2513 \\
\hline \multirow{2}{*}{$\begin{array}{c}27 \text { and } \\
\text { above }\end{array}$} & Mean & 4,4194 & 2,9250 & 3,9750 & 4,4000 & 4,1104 \\
\cline { 2 - 7 } & St. Dev. & 0,2508 & 0,6487 & 0,3073 & 0,3476 & 0,3324 \\
\hline \multicolumn{2}{|c|}{ p- value } & $0,006^{*}$ & $0,002^{*}$ & 0,288 & $0,000 *$ & $0,007 *$ \\
\hline
\end{tabular}

"Competence - mastery" sub-dimension average scores do not differ significantly according to the age groups of individuals. "Intellectual" sub-dimension average scores of individuals aged 27 and above are higher than sub-age groups, "social" sub-dimension average scores are lower than sub-age groups, "overall scale" average scores are higher than sub-age groups. Individuals aged 24 and above have higher mean scores for the "unattractive - attractive" sub-dimension than the 18-20 and 21-23 age groups.

Table 8. The Results of the Students' Participation in Recreational Activities by Education Level of Mother

\begin{tabular}{|c|c|c|c|c|c|c|}
\hline $\begin{array}{c}\text { Mother's } \\
\text { Education } \\
\text { Level }\end{array}$ & Intellectual & Social & $\begin{array}{c}\text { Qualification - } \\
\text { Mastery }\end{array}$ & $\begin{array}{c}\text { Unattractive - } \\
\text { Attractive }\end{array}$ & $\begin{array}{c}\text { Overall } \\
\text { Scale }\end{array}$ \\
\hline \multirow{2}{*}{ Illiterate } & Mean & 4,2500 & 4,0000 & 4,3750 & 4,0625 & 4,1719 \\
\cline { 2 - 7 } & St. Dev. & 0,4330 & 0,1443 & 0,5773 & 0,0721 & 0,3067 \\
\hline $\begin{array}{c}\text { Primary } \\
\text { Education }\end{array}$ & Mean & 4,0527 & 3,4684 & 3,9004 & 4,1309 & 3,9131 \\
\cline { 2 - 8 } & St. Dev. & 0,7575 & 0,6099 & 0,5055 & 0,6536 & 0,5155 \\
\hline \multirow{2}{*}{$\begin{array}{c}\text { Schigh } \\
\text { School }\end{array}$} & Mean & 4,0469 & 3,4896 & 3,6302 & 4,2708 & 3,8594 \\
\cline { 2 - 8 } & St. Dev. & 0,4507 & 0,6889 & 0,6507 & 0,5305 & 0,4359 \\
\hline \multirow{2}{*}{ Bachelor } & Mean & 4,0921 & 3,3895 & 3,8618 & 3,9276 & 3,7928 \\
\cline { 2 - 8 } & St. Dev. & 0,2721 & 0,5150 & 0,5663 & 0,6707 & 0,2922 \\
\hline \multirow{2}{*}{$\begin{array}{c}\text { Master } \\
\text { Degree }\end{array}$} & Mean & 2,6250 & 1,3750 & 2,5000 & 2,3750 & 2,2188 \\
\cline { 2 - 8 } & St. Dev. & 0,0000 & 0,0000 & 0,0000 & 0,0000 & 0,0000 \\
\hline \multicolumn{2}{|c|}{ p- value } & $0,0013^{*}$ & $0,000^{*}$ & $0,000^{*}$ & $0,000^{*}$ & $0,000^{*}$ \\
\hline
\end{tabular}

When the distributions of the scale according to the education level of the mothers of the individuals are examined, the "intellectual", "social" and "competence - mastery" sub-dimension mean score values are highest in individuals whose mothers are illiterate and the lowest in individuals whose mothers are master degree graduates. The "Unattractive - Attractive" subdimension mean score values of the individuals whose mothers are graduate are lower than the other individuals. Looking at the overall scale, it is seen that the higher the education level of the mother is, the lower the mean scores of the overall scale are. 
Table 9. The Results of the Students' Participation in Recreational Activities by Education Level of Father

\begin{tabular}{|c|c|c|c|c|c|c|}
\hline $\begin{array}{c}\text { Father's } \\
\text { education } \\
\text { level }\end{array}$ & Intellectual & Social & $\begin{array}{c}\text { Qualification } \\
\text { - Mastery }\end{array}$ & $\begin{array}{c}\text { Unattractive - } \\
\text { Attractive }\end{array}$ & $\begin{array}{c}\text { Overall } \\
\text { Scale }\end{array}$ \\
\hline \multirow{2}{*}{$\begin{array}{c}\text { Primary } \\
\text { Education }\end{array}$} & Mean & 4,2031 & 3,6763 & 3,9308 & 4,1138 & 3,9810 \\
\cline { 2 - 7 } & St. Dev. & 0,5082 & 0,5962 & 0,5139 & 0,6375 & 0,4643 \\
\hline $\begin{array}{c}\text { High } \\
\text { School }\end{array}$ & Mean & 4,0298 & 3,4630 & 3,8241 & 4,2321 & 3,8006 \\
\cline { 2 - 7 } & St. Dev. & 0,5842 & 0,5975 & 0,6174 & 0,4524 & 0,3736 \\
\hline \multirow{2}{*}{ Bachelor } & Mean & 3,9306 & 3,2857 & 3,6548 & 4,0556 & 3,8183 \\
\cline { 2 - 7 } & St. Dev. & 0,5871 & 0,6224 & 0,6184 & 0,7230 & 0,4600 \\
\hline \multirow{2}{*}{$\begin{array}{c}\text { Master } \\
\text { Degree }\end{array}$} & Mean & 3,6250 & 2,1875 & 3,2500 & 3,1250 & 3,0469 \\
\cline { 2 - 7 } & St. Dev. & 1,1547 & 0,9381 & 0,8660 & 0,8660 & 0,9562 \\
\hline \multicolumn{2}{|c|}{ p- value } & $0,040^{*}$ & $0,000^{*}$ & $0,034 *$ & $0,010 *$ & $0,001 *$ \\
\hline
\end{tabular}

When the distributions of scale are examined according to the education level of the fathers of the individuals, the "intellectual", "social" and "competence-mastery" sub-dimension average score values decrease as the education level of the father increases. In addition, individuals whose fathers are graduate graduates have lower "Unattractive - Attractive" sub-dimension and "overall scale" average scores than other individuals.

Table 10. The Results of the Students' Participation in Recreational Activities by Monthly Total Income Levels of the Families

\begin{tabular}{|c|c|c|c|c|c|c|}
\hline $\begin{array}{c}\text { Family total } \\
\text { monthly } \\
\text { income level }\end{array}$ & & Intellectual & Social & $\begin{array}{l}\text { Qualification } \\
\text { - Mastery }\end{array}$ & $\begin{array}{l}\text { Unattractive - } \\
\text { Attractive }\end{array}$ & $\begin{array}{c}\text { Overall } \\
\text { Scale }\end{array}$ \\
\hline \multirow[t]{2}{*}{$1001-2000 \mathrm{TL}$} & Mean & 4,5313 & 4,1563 & 4,2813 & 4,2500 & 4,3047 \\
\hline & St. Dev. & 0,1108 & 0,5033 & 0,3938 & 0,3659 & 0,2666 \\
\hline \multirow[t]{2}{*}{$2001-3000 \mathrm{TL}$} & Mean & 4,0556 & 3,3542 & 3,7500 & 3,8958 & 3,7639 \\
\hline & St. Dev. & 0,5431 & 0,6170 & 0,4724 & 0,6370 & 0,3845 \\
\hline \multirow{2}{*}{$\begin{array}{l}\text { 3001 TL and } \\
\text { above }\end{array}$} & Mean & 4,0100 & 3,4431 & 3,7846 & 4,1551 & 3,8482 \\
\hline & St. Dev. & 0,6066 & 0,6573 & 0,6358 & 0,6589 & 0,4990 \\
\hline \multicolumn{2}{|c|}{ p-value } & 0,051 & $0,006^{*}$ & 0,064 & 0,090 & $0,014 *$ \\
\hline
\end{tabular}

There is no significant difference between "intellectual", "competences - mastery" and "unattractive - attractive" sub-dimension average score values according to the monthly total income levels of the families of the individuals. In addition, the "social" sub-dimension and the "overall scale" average score values of the group whose family monthly income is $1001-2000$ $\mathrm{TL}$, that is the lowest income group, are higher than the groups with higher income.

Table 11. The Results of the Students' Participation in Recreational Activities by Recreation Department 


\begin{tabular}{|c|c|c|c|c|c|c|}
\hline $\begin{array}{c}\text { Which faculty would } \\
\text { you like the recreation } \\
\text { department to be in? }\end{array}$ & Intellectual & Social & $\begin{array}{c}\text { Qualification } \\
\text { - Mastery }\end{array}$ & $\begin{array}{c}\text { Unattracti } \\
\text { ve - } \\
\text { Attractive }\end{array}$ & $\begin{array}{c}\text { Overall } \\
\text { Scale }\end{array}$ \\
\hline $\begin{array}{c}\text { Faculty of Sport } \\
\text { Sciences }\end{array}$ & Mean & 3,9741 & 3,1509 & 3,6724 & 3,8966 & 3,6735 \\
\cline { 2 - 7 } & St. Dev. & 0,6063 & 0,5780 & 0,5180 & 0,7899 & 0,4477 \\
\hline Faculty of Tourism & Mean & 4,0640 & 3,5295 & 3,8317 & 4,1467 & 3,8930 \\
\cline { 2 - 7 } & St. Dev. & 0,5828 & 0,6585 & 0,6148 & 0,6069 & 0,4755 \\
\hline p- value & & 0,458 & $0,005 *$ & 0,198 & 0,061 & $0,025^{*}$ \\
\hline
\end{tabular}

The opinions of the individuals about "which faculty the recreation department should be in" do not make a difference on the average score values of the "intellectual", "competence - mastery" and "un attractive - attractive" sub-dimensions. However, the average scores of the "social" subdimension and "overall scale" of the individuals who want the recreation department to be in the Faculty of Tourism are higher than the individuals who want the recreation department to be in the Faculty of Sport Sciences.

Table 12. The Results of the Students' Participation in Recreational Activities by the Effects of Games

\begin{tabular}{|c|c|c|c|c|c|c|}
\hline $\begin{array}{c}\text { How effective are } \\
\text { games in } \\
\text { recreational } \\
\text { activities? }\end{array}$ & Intellectual & Social & $\begin{array}{c}\text { Qualific } \\
\text { ation - } \\
\text { Master } \\
\mathbf{y}\end{array}$ & $\begin{array}{c}\text { Unattra } \\
\text { ctive - } \\
\text { Attracti } \\
\text { ve }\end{array}$ & $\begin{array}{c}\text { Overall } \\
\text { Scale }\end{array}$ \\
\hline \multirow{2}{*}{ Very efficient } & Mean & 4,0484 & 3,4409 & 3,7810 & 4,0969 & 3,8418 \\
\cline { 2 - 7 } & St. Dev. & 0,5884 & 0,6529 & 0,6321 & 0,6670 & 0,4795 \\
\hline Slightly effective & Mean & 4,0417 & 3,5463 & 3,9028 & 4,1157 & 3,9016 \\
\cline { 2 - 7 } & St. Dev. & 0,5873 & 0,6952 & 0,4048 & 0,5685 & 0,4693 \\
\hline \multicolumn{2}{|c|}{ p- value } & 0,957 & 0,452 & 0,339 & 0,891 & 0,555 \\
\hline & & & & & & \\
\hline
\end{tabular}

The individuals' "opinions about how much the games in recreational activities are effective" do not make a significant difference on the "overall scale" and sub-dimensions.

Table 13. The Results of the Students' Participation in Recreational Activities by the Type of Recreational Activity

\begin{tabular}{|c|l|c|c|c|c|c|}
\hline $\begin{array}{c}\text { What kind of } \\
\text { recreational } \\
\text { activities do you do } \\
\text { in your leisure } \\
\text { time? }\end{array}$ & Intellectual & Social & $\begin{array}{c}\text { Qualificati } \\
\text { on - } \\
\text { Mastery }\end{array}$ & $\begin{array}{c}\text { Unattrac } \\
\text { tive - } \\
\text { Attractiv } \\
\text { e }\end{array}$ & $\begin{array}{c}\text { Overall } \\
\text { Scale }\end{array}$ \\
\hline Sports & Mean & 3,9350 & 3,3650 & 3,8700 & 4,0800 & 3,8125 \\
\hline
\end{tabular}




\begin{tabular}{|c|c|c|c|c|c|c|}
\hline & St. Dev. & 0,6104 & 0,8221 & 0,5830 & 0,7256 & 0,5699 \\
\hline \multirow{2}{*}{ Other activities } & Mean & 4,1002 & 3,5035 & 3,7700 & 4,1097 & 3,8709 \\
\cline { 2 - 7 } & St. Dev. & 0,5699 & 0,5657 & 0,6075 & 0,6135 & 0,4277 \\
\hline \multicolumn{2}{|c|}{ p- value } & 0,101 & 0,222 & 0,333 & 0,791 & 0,477 \\
\hline
\end{tabular}

According to the type of recreational activity individuals do in their leisure time, the average score values of the "overall scale" and its sub-dimensions do not show a significant difference.

\section{Discussion and Conclusion}

Within the scope of the research, it was aimed to determine the recreational activity choices of the students studying at various faculties in universities in Izmir.

Only the "unattractive - attractive" sub-dimension mean score values of the individuals show a statistically significant difference according to their gender $(\mathrm{p}<0.05)$. Accordingly, the unattractive - attractive factors are more important in the selection of recreational activities for women. Mean score values of women are higher than men. There is no difference between overall and other sub-dimensions. It is seen that gender is not one of the factors affecting the participation of individuals in leisure activities. According to Moccia (2000), gender plays an important role in preferring leisure activities. Culp (1998) stated that gender is a very important part of social impact and it is an important factor limiting leisure time activities of individuals. Demir and Demir (2006) explained that gender is one of the most important factors affecting the participation of individuals in leisure activities. They contradict with our study. We see that gender does not play an important role in preferring leisure activities. We think as gender does not have an important role, the education levels of the individuals are high and their feelings and thoughts are similar, there is no difference between them.

According to the income levels of individuals, "social", "unattractive - attractive" sub-dimension average score values and "overall scale" mean scores do not differ significantly ( $p>0.05)$. In addition, "intellectualism" is more important in the selection of recreational activities of individuals with an income of $1000 \mathrm{TL}$ and below than individuals with higher income. "Competence - mastery" sub-dimension mean score values are higher for individuals with an income of $1501 \mathrm{TL}$ and above than the individuals with less income $(\mathrm{p}<0.05)$. There is no significant difference in other sub-dimensions. Demir and Demir (2006); Jackson (1990); Searle and Jackson (1985) found in their study that individuals with high income tend to participate more in leisure time activities because there is a relationship between the income levels of individuals and their preference for leisure activities. It does not support our study. We can say that students are aware that participation in recreational activities is important for every individual, even if their income level is different. All kinds of recreational activities are now provided by the health, culture and sports departments of universities and sports departments of municipalities to individuals for free. Regardless of the economic status of the individuals, it is ensured that every individual can benefit equally from the participation opportunities in recreational activities. Therefore, we can say that the level of income does not affect the participation in recreational activities.

"Competence - mastery" sub-dimension mean scores do not differ significantly according to the age groups of individuals $(\mathrm{p}>0.05)$. "Intellectual" sub-dimension mean scores of individuals aged 27 and above are higher than sub-age groups, "social" sub-dimension mean scores are lower than sub-age groups, "overall scale" mean scores are higher than sub-age groups. Individuals aged 24 and above have higher mean scores for the "unattractive - attractive" sub-dimension than the 1820 and 21-23 age groups. Similar studies to our study have been reached. They support the study we have done. In the study of Demir and Demir (2006), age is one of the important factors affecting participation in leisure activities. We can say that age affects participation in recreational activities. We can state that as the age of individuals changes, their expectations also change. We 
can state that an elderly individual has different expectations from a young person about participating in recreational activities.

When the distributions of the scale according to the educational level of the mothers of the individuals is examined, the mean scores of the "intellectual", "social" and "competence-mastery" sub-dimensions are the highest in individuals whose mothers are illiterate and the lowest in individuals whose mothers are master's degree graduates $(p<0.05)$. The "unattractive - attractive" sub-dimension mean score values of the individuals whose mothers are master degree graduates are lower than the other individuals. Looking at the overall scale, it is seen that the higher the education level of the mother is, the lower the mean scores of the overall scale are. As a result of the study we have done, we can say that education and recreational activities are effective on participation. As the education level of individuals' mothers increases, their perspective on life also changes, so we can say that education level is effective on participating in recreational activities.

When the distributions of the scale are examined according to the educational level of the fathers of the individuals, the mean score values of the "intellectual", "social" and "competence-mastery" sub-dimensions decrease as the educational level of the father increases $(\mathrm{p}<0.05)$. In addition, the mean scores of the "unattractive - attractive" sub-dimension and the "overall scale" of the individuals whose fathers are master's degree graduate are lower than the other individuals $(\mathrm{p}<0.05)$. We can say that as the education level changes, the expectations of the individuals also change. We can say that as the level of education increases, the perspective of the individual on life also changes. Thanks to education, individuals know what they want from life. In short, we can state that the level of education is effective on participating in recreational activities. No findings were obtained to support our study.

There is no significant difference between "intellectual", "competence - mastery" and "unattractive - attractive" sub-dimension mean score values according to the monthly total income levels of the families of the individuals ( $p>0.05$ ). In addition, the "social" sub-dimension and "overall scale" average score values of the group with the monthly family income between 1001$2000 \mathrm{TL}$, that is, the lowest income group, are higher than the groups with higher income $(\mathrm{p}<0.05)$. We can state that the income level is not very effective on participating in recreational activities. Both universities and municipalities provide students to participate in recreational activities. We can say that only students who will participate in recreational activities can participate in activities according to the program. According to the characteristics of the social state, each individual's participation in recreational activities should be provided. No findings were obtained to support our study.

The opinions of the individuals about "which faculty the recreation department should be in" do not make a difference on the mean score values of the "intellectual", "competence - mastery" and "unattractive - attractive" sub-dimensions ( $p>0.05$ ). However, the mean score values of the "social" sub-dimension and "overall scale" of the individuals who want the recreation department to be in the Faculty of Tourism are higher than the individuals who want the recreation department to be in the Faculty of Sport Sciences $(\mathrm{p}<0.05)$. Since this study was carried out only in the tourism faculty, the recreation department was high in these faculties. The mission of the recreation departments is to prepare their students in accordance with this mission and to gain skills. Universities at the top level of education should train their students in the recreation department before graduation. Some skills that will enable students to use their leisure time effectively after graduation should be provided to students. In this way, students who graduate from the recreation department will be able to spend their leisure time consciously in a social sense. No matter the recreation department is in the faculty of sports sciences or in the tourism faculty, the aim is to make the individuals spend their leisure time best.

The individuals' "opinions about how much the games in recreational activities are effective" do not make a significant difference on the "overall scale" and its sub-dimensions of ( $p>0.05)$. We can state that while some of the games are very effective, some of them are slightly effective for the students. We can mention that the game in recreational activities is extremely effective on children and young people. Game is extremely important for children's development. Since game is not very important for the elderly, we can say that physical activity is important for them. Physical activity plays an important role in delaying and preventing musculoskeletal disorders 
such as mechanical back pain, shoulder and neck pain, osteoporosis and related fractures (Şahin, 2002). There are no findings to support our study.

According to the type of recreational activity that individuals do in their leisure time, the average score values of the "overall scale" and its sub-dimensions do not show a significant difference $(\mathrm{p}>0.05)$. We can say that individuals participate in both sports and other activities in their leisure time. Apart from sports, individuals read books and newspapers, listen to music, watch TV, go to cinema and theater, deal with crafts and arts requiring skills, deal with social activities, paint, go to disco, bar, pub (tavern, pub) etc., participate in cultural and scientific activities, watch sports competitions (by going to the facilities), participate in social activities. In other words, individuals participate in other activities apart from sports. We can say that young people at the university become conscious and participate in both social and sports activities. All in all, we can mention that individuals are active in social areas.

As a result of the research, when the factors affecting students' participation in recreational activities are examined, it has been concluded that the factor with the highest average is "to discover new things". The statement with the lowest average in the scale is "to gain the respect of others". In addition, according to the sub-dimension averages, it is seen that the most effective factor in the participation of individuals in recreational activities is the unattractive - attractive factors, and the least important factor is sociability. Since this study only covers a limited number of tourism faculty students, it is recommended to other researchers that similar studies about other sports sciences faculties should be done in this topic.

\section{References}

Beard, J. G. ve Ragheb, M. G. (1983). Measuring Leisure Motivation, Journal of Leisure Research, 15 (3): 219-228.

Beard, J. G., Ragheb, M. G. (1980). Measurement Leisure Satisfaction, Journal of Leisure Research, 12 (1), 20-33.

Beggs, A. B. ve Elkins, S. J. (2010). The Influence of Leisure Motivation on Leisure Satisfaction. ABD: Illinois Devlet Üniversitesi.

Beggs, A. B., Elkins, S. J., Stitt, J. E. (2004). Leisure Motivation Of Participants And Nonparticipants in Campus Recreational Sports Programs, Recreational Sports Journal, 1: $65-76$.

Broadhurst R.(2001). Managing Environments For Leisure And Recreation, London, GBR:Rotledge, S. 3.

Culp, R. H. (1998): "Adolescent Girls and Outdoor Recreation: A Case Study Examining Constraints and Effective Programming." Journal of Leisure Research, 30(3), 356-379.

Demir C.(2003). Demografik Özellikler İle Sağlanan İmkânların Sportif Faaliyet Tercihleri Üzerine Etkileri; Üniversite Gençliğine Yönelik Bir Uygulama, 1. Gençlik, Boş Zaman ve Doğa Sporları Sempozyumu, Ankara: Türk Hava Kurumu Basım Evi İşletmeciliği.

Demir, C., Demir, D. (2006). "Bireylerin Boş Zaman Faaliyetlerine Katılmalarını Etkileyen Faktörler İle Cinsiyet Arasındaki İlişki: Lisans Öğrencilerine Yönelik Bir Uygulama”, Ege Üniversitesi iktisadi ve İdari Bilimler Fakültesi, Ege Akademik Bakış Dergisi, 6 (1), 3648.

Jackson, P. W. (1990). Life In Classrooms: Teachers College Press. New York.

Kanters, MA. ve Forrester, S. (1997). The Motivations and Self-esteem of Intramural Sports Participants, NIRSA Journal, 21: 3-7.

Karlı, Ü., Polat, E., Yılmaz, B. ve Koçak S. (2008). Serbest Zaman Tatmin Ölçeğinin Geçerlik ve Güvenirlik Çalışması, Spor Bilimleri Dergisi, 19(2), 80-91.

Kement, Ü., Çavuşoğlu, S., \& Uslu, A. (2019). Turizm Eğitimi Gören Öğrencilerin Kişilik Özelliklerinin Kültürel Zekâ Düzeylerine Etkisi. Anatolia: Turizm Araştırmaları Dergisi, 30 (1), 57-68.

Lounsbury, J.W., Polik, J.R. (1992). Leisure Needs and Vacation Satisfaction, Leisure Sciences: An Interdisciplinary Journal, 14 (2): 105-119. 
Mete, B., Ağaoğlu S.A.(2003). Ondokuz Mayıs Üniversitesi Kurupelit Kampusü Akademik ve İdari Personelin Rekreatif Aktivitelere Katılım ve Bakışaçılarının İncelenmesi. Beden Eğitimi ve Sporda Sosyal Alanlar Kongresi, 421-426, Ankara.

Moccia, F.D. (2000): "Planning Time: An Emergent European Practice." European Planning Studies, 8(3), 367-376.

Özdemir S, Karaküçük S, Gümüş M., \& Kıran, S. (2006). Türkiye Taş Kömürü Kurumu Genel Müdürlüğü'nde Çalışan Yeraltı İşçilerinin Boş Zamanlarını Değerlendirme Alışkanlıklarının Belirlenmesi, 9. Uluslararası Spor Bilimleri Kongresi, Bildiri Kitabı, Muğla, S.10.

Ryan, C., Glendon, I. (1998). Application of Leisure Motivation Scale to Tourism, Annals of Tourism Research, 1: $169-184$.

Searle, MS., Jackson, EL. (1985). Socioeconomic Variations İn Perceived Barriers To Recreation Participation Among Would- Be Participants. Leisure sciences, 7(2), 227-249.

Soybalı, H. H., Kabakulak, A., \& Başar, B. (2020). Üniversite Öğrencilerinin Kişilik Özelliklerinin Rekreasyon Faaliyetlerine Katilim Düzeyi Üzerindeki Etkisi: Afyon Kocatepe Üniversitesi Örneği. Journal of Recreation and Tourism Research, 7 (2), 107 134.

Starzyk, K.B., Reddon, J.R., \& Friel, J.P. (2000). Need Structure, Leisure Motivation, and Psychosocial Adjustment Among Young Offenders and High School Students, Journal of Offender Rehabilitation, 1 (2): 163 - 174.

Şahin, Z. (2002). Ergenlerde Fiziksel Aktivite Düzeyinin Değerlendirilmesi. Bilim Uzmanlığ1 Tezi. Hacettepe Üniversitesi, Sağlık Bilimleri Enstitüsü.

Tezcan, M. (1993). Boş Zamanlar Sosyolojisi. Ankara Üniversitesi Eğitim Bilimleri Fakültesi Yayınları, Ankara.

Tolukan, E. (2010). Özel Yetenekle İlgili Bölümlerde Okuyan Üniversite Öğrencilerinin Rekreasyonel Aktivitelere Katılımlarına Engel Olabilecek Unsurların Belirlenmesi. Yüksek Lisans Tezi, Niğde Üniversitesi, Sosyal Bilimler Enstitüsü.

Yağmur, R. (2006). Afyon Kocatepe Üniversitesi Beden Eğitimi ve Spor Yüksekokulu Öğrencilerle Farklı Bölümlerdeki Öğrencilerin Serbest Zaman Aktivitelerinin Karşılaştırılması. Yüksek Lisans Tezi, Afyon Kocatepe Üniversitesi Sağlı Bilimleri Enstitüsü.

Yağmur, Y. (2015). Üniversite Öğrencilerinin Sosyalleşme Süreci ve Rekreasyon Aktivitelerinin İncelenmesi: Erciyes Üniversitesi Örneği. Yüksek Lisans Tezi, Akdeniz Üniversitesi, Sosyal Bilimler Enstitüsü, Antalya.

Yağmur, Y., \& İçigen, E.T. (2016). Üniversite öğrencilerinin sosyalleşme süreci ve rekreasyon faaliyetlerinin incelenmesi üzerine bir çalışma. Anatolia: Turizm Araştırmaları Dergisi, 27(2), 227-242.

Yetim, A. (2005). Sosyoloji ve Spor. İstanbul: Yaylacık Matbaası.

Yurcu, G. (2017). Turistlerin Kişilerarası İlişki Tarzları, Boş Zaman Motivasyonları ve Boş Zaman Tatminleri İlişkisi: AntalyalKemer|Beldibi örneği. Journal of Tourism and Gastronomy Studies, 200-226. 